\title{
RAGAM HIAS NON-CERITA PADA RELIEF CANDI UNTUK PERKEMBANGAN MOTIF BATIK KONTEMPORER
}

\author{
T. M. Rita Istari* \\ BalaiArkeologi Yogyakarta, Jalan Gedongkuning 174, Kotagede, Yogyakarta 55171; \\ Telepon: (0274) 3779913; Facsimile (0274) 3779913
}

\begin{abstract}
Abstrak. Ragam hiasan merupakan sarana komunikasi untuk menyampaikan suatu pesan kepada masyarakat luas. Proses penciptaannya tidak lepas dari pengaruh lingkungan dan berperan sebagai media untuk memperindah suatu karya seni manusia. Kemunculan ragam hiasan di Indonesia dimulai sejak masa prasejarah. Kemudian, ragam hiasan mengalami perkembangan dari masa ke masa sampai dengan masuknya kebudayaan HinduBuddha ke Indonesia. Tulisan ini membahas sejumlah ragam hias relief candi yang mempunyai makna magisreligius dan diaplikasikan sebagai motif pada kain batik. Dengan demikian, metode yang dipakai untuk kajian ini adalah deskriptif-eksplanatif dengan penalaran induktif, sedangkan pengumpulan data dilakukan dengan studi pustaka dan pengamatan langsung di lapangan. Hasil kajian menunjukkan masyarakat di Nusantara memiliki local genius dalam menciptakan identitas baru yang sesuai dengan kebudayaannya dari hasil perkawinan budaya lokal dan Hindu-Buddha. Gagasan semacam ini diharapkan dapat meningkatkan inspirasi dan mendorong inovasi kreasi-kreasi baru, tetapi tetap memperlihatkan karakteristik khas warisan budayanya.
\end{abstract}

Kata kunci: relief candi, ragam hiasan, local genius, motif batik, transformasi budaya, warisan budaya, identitas

\begin{abstract}
TEMPLE RELIEF ORNAMENTS AS BATIK MOTIFS. Ornaments are means of communication to convey a message to the society. The creation process cannot be separated from the environmental influences and it serves as a medium to embellish human's work of art. The appearance of ornaments in Indonesia began in the prehistoric periods. Thereafter, ornaments had been evolving from time to time until Hinduism-Buddhism culture arrived in Indonesia. This paper discusses a number of temple relief ornaments that have magicalreligious meaning and applied as motifs on the batik cloth. Thus, the method used in this study is descriptiveexplanative with inductive reasoning, while the data collection is done by literature studies and direct observations in the field. The results of the study showed people in the Indonesian archipelago has local genius in creating a new identity in accordance with their culture derived from the marriage of local and Hindu-Buddhist culture. Such idea is expected to be able to increase inspiration and encourage innovation of new creations, yet still showing typical characteristics of their cultural heritages.
\end{abstract}

Keywords: temple reliefs, various ornaments, local genius, batik motifs, cultural transformation, cultural heritage, identity

* Penulis adalah peneliti madya pada Balai Arkeologi Yogyakarta, email: ritaistari@yahoo.com 
Ragam Hias Non-Cerita pada Relief Candi

untuk Perkembangan Motif Batik Kontemporer 64-78

\section{A. Pendahuluan}

Manusia dan kebudayaan merupakan kesatuan yang erat karena hasrat untuk memenuhi kebutuhan hidup menimbulkan karya-karya yang bagus. Kebudayaan neolitik adalah kebudayaan pertama yang tersebar di Indonesia dan menjadi dasar kebudayaan bangsa Indonesia selanjutnya (Koentjaraningrat 1990, 18). Budaya neolitik dikatakan menjadi dasar kebudayaan di dunia pada umumnya dan di Indonesia khususnya. Zaman itu manusia sudah merubah hidupnya dari food-gathering menjadi food-producing, saat itu orang sudah bertempat tinggal menetap dan telah mempunyai kepandaian bercocok tanam di ladang dengan menanam umbi-umbian dan membuat peralatan memasak dari tanah liat. Mereka beranggapan dalam mencapai tujuan tertentu perlu diciptakan segala sesuatu yang bagus yang berhubungan dengan magis dan bersumber kepada religi. Kata religi berasal dari bahasa Latin relique, yang berarti bendabenda keramat peninggalan seseorang yang dipandang suci dengan demikian yang akan dijadikan objek penghormatan, juga dianggap dapat menghubungkan kembali manusia dengan asalnya (Wagner 1959, 19). Alat untuk menghubungkan kembali ke asalnya diperoleh manusia dengan menciptakan suatu karya seni dari pengalaman sebagai hasil religius dan pemujaan kepada leluhur, sedangkan kepercayaan manusia menghormati karya seni itu terkait dengan adat yang berakar kepada mitos dan tradisi.

Sebelum berkembangnya kebudayaan Hindu-Buddha, di Indonesia sudah terdapat banyak karya seni dari jaman prasejarah. Karya seni itu antara lain beliung yang digosok halus dari kebudayaan megalitik seperti dolmen, menhir, dan sarkofagus. Kemudian tinggalan arkeologi dari budaya perunggu yang pertama ditemukan di Dongson, Indo Cina Utara, berupa nekara, dan kapak perunggu. Pada permukaan nekara dihiasi ornamen-ornamen seperti garis-garis, meander, tumpal, dan spiral (Sunarya 2009, 8). Peralatan memasak yang dibuat dari tanah liat dengan hiasan geometris ditemukan dalam penggalian-penggalian arkeologi. Datangnya budaya Hindu dan Buddha bukannya melenyapkan kebudayaan nenek moyang yang sudah ada, melainkan membawa pengaruh adanya suatu kepandaian baru yaitu menulis, yang selanjutnya memperkaya kebudayaan bangsa Indonesia. Oleh sebab itu, kemudian muncul inspirasi karya seni yang digoreskan pada bangunan-bangunan suci sebagai rumah para dewa yang dinamakan ornamen atau ragam hias yang mengandung unsur-unsur mistik yang berhubungan dengan kepercayaan dan keagamaan. Menurut Niewenkamp dalam Covarrubias $(1973,95)$ ornamen-ornamen atau ragam hias itu menggambarkan perwujudan jiwa dan objek alam yang distilisasi, sehingga terbentuk seni lukis ataupun ukir sesuai dengan kemampuan senimannya, yang akhirnya berkembang menjadi dasar pola-pola tertentu yang bersifat turun temurun.

Pada waktu kebudayaan HinduBuddha masuk ke Indonesia, ragam hias terdapat pada bangunan-bangunan candi. Pada umumnya ragam hias tersebut mengandung nilai simbolis terkait dengan kepercayaan yang dianutnya. Motif hias manusia tidak lagi menggambarkan sosok nenek moyang yang kaku. Melainkan akibat 
pengaruh dari kebudayaan Hindu-Buddha tersebut, manusia digambarkan dalam bentuk tokoh manusia atau dewa dengan berbagai sikap dan atribut. Demikian pula ragam hias tumbuhan digambarkan secara alami (naturalis), nyata (realis), dan digayakan (stiliran). Sementara itu, binatang yang sering digambarkan adalah jenis binatang unggas, binatang merayap, binatang berkaki empat, dan binatang khayali (mistis) (Hoop 1949, 1115). Ragam hias merupakan gambaran yang menyatakan keadaan diri dan lingkungan penciptanya. Bila ragam hias tersebut dipakai terus menerus dan menjadi kebiasaan masyarakat maka akan menjadi suatu tradisi. Ragam hias dibuat dengan tujuan untuk memperindah suatu bentuk atau suatu karya oleh pembuatnya. Jenis-jenis ragam hias terdapat pada setiap kelompok masyarakat yang tersebar di seluruh wilayah Kepulauan Indonesia. Masing-masing wilayah tersebut mempunyai jenis ragam hias yang sudah eksis dan menjadi ciri khas dari suatu wilayah tertentu tampak pada hasil-hasil kebudayaan misalnya, berupa karya-karya seni dalam bentuk kain batik, tenun, dan ukiran pada kayu. Sebagai contoh dapat dilihat pada kain batik dari Jawa, tenun dari Toraja, Flores, dan Bali, ataupun seni ukir kayu dari Kalimantan, Toraja, Bali, dan Irian. Siapapun yang melihat hasil karya itu tentu akan langsung mengetahui karya seni tersebut berasal darimana. Tentunya karya seni itu muncul dari budaya seni masa lampau yang diciptakan oleh generasi terdahulu, yang kemudian diwariskan secara turun temurun ke generasi berikutnya dengan mengalami berbagai perkembangan. Hal tersebut juga dapat dijumpai pada bangunan-bangunan di wilayah Indonesia yang banyak berhiaskan ragam ornamen tradisional yang meniru bangunan candi sebagai tinggalan masa lampau. Ornamen pada bangunan candi terdapat hampir di seluruh komponen bangunan candi seperti pada kaki, tubuh, dan atap candi.

\section{B. Ragam Hias pada Relief Candi}

Candi adalah peninggalan arsitektural dari Masa Klasik Indonesia sejak abad V-XV Masehi. Penyebaran candi dalam periode Klasik terdapat hampir di seluruh kepulauan Indonesia, meskipun yang terbanyak adalah candi-candi yang berada di Pulau Jawa, khususnya di Daerah Istimewa Yogyakarta, Jawa Tengah dan Jawa Timur yang pernah mempunyai kerajaan besar pada masanya. Di balik bentuk fisik candi terkandung nilai-nilai dan pesan spiritual, yang menjadi intisari penciptaan tersebut melalui seni bangun, seni arca, dan seni hias candi (relief), yang dianggap dapat menghubungkan manusia untuk mencapai dunia nirwana.

Bangunan candi Hindu dan Buddha, sebagian besar mempunyai relief-relief yang dapat dikategorikan dalam tiga jenis (Simanjuntak 2008, 108-111) yaitu:

1. Relief Cerita (Naratif) Jenis relief ini memvisualisasikan suatu bentuk cerita yang menggambarkan cerita keagamaan atau pun cerita yang bersifat pendidikan. Cerita tersebut dipahatkan pada sejumlah panil yang kisahnya berangkai dari panil ke panil. Pembacaannya dapat searah jarum jam (pradaksina) atau pun berlawanan arah jarum jam (prasawya); 
2. Relief Candrasengkala

Relief tersebut merupakan relief yang digambarkan dalam bentuk figur-figur manusia, hewan atau makhluk mitologis yang harus diartikan dalam bentuk kalimat. Kalimat yang terbentuk, mengandung arti angka tahun;

3. Relief Non- Cerita

Relief jenis ini banyak ragamnya, dipahat pada bermacam bangunan. Digambarkan dalam bentuk simbol dari konsep agama tertentu, dan dapat dibagi menjadi:

a. Relief Hiasan Geometris

b. Relief Simbol Mitologi-Religius.

Ragam hias dapat juga dikelompokkan secara lebih sederhana berdasarkan bentuk-bentuknya menjadi, ragam hias bentuk geometris, tumbuhtumbuhan, manusia, dan binatang.

\section{Ragam Hias Bentuk Geometri}

Ragam hias ini berdasarkan hasil penelitian dapat dianggap sebagai bentuk tertua yang kemudian mengalami perkembangan dengan masuknya kebudayaan lain. Bentuk ragam hias ini antara lain adalah:

a. Tumpal, memiliki bentuk dasar bidang segitiga, berderet ke samping;

b. Meander, merupakan hiasan pinggir yang bentuk dasarnya berupa garis berliku atau berkelok-kelok;

c. Pilin, bentuk dasarnya merupakan garis lengkung spiral atau lengkung kait. Dapat dibedakan menjadi pilin tunggal yang berbentuk ikal, pilin ganda berbentuk dasar huruf $S$, dan pilin tegar yaitu bentuk ikal bersambung dan berganti arah; d. Swastika/Banji, memiliki dasar garis tekuk yang bersilangan mirip bentuk baling-baling dan swastika. Swastika adalah lambang bintang-bintang dan matahari;

e. Kawung, dengan dasar berupa bentuk-bentuk lingkaran yang saling berpotongan berjajar ke kiri kanan atau ke atas bawah;

f. Jlamprang, bentuk berupa lingkaranlingkaran yang berjajar dan bersinggungan, di tengahnya diisi dengan pola-pola hias tumbuhtumbuhan atau geometris;

g. Kertas tempel, berupa pengulangan suatu pola tertentu, digunakan untuk menghiasi bidang-bidang di bagian luar dinding (Hoop 1949, 26-91).

\section{Ragam Hias Bentuk Tumbuh- tumbuhan}

Bentuk tumbuh-tumbuhan merupakan ragam hias yang terdiri atas satu tangkai atau lebih dengan bunga-bunganya yang distilisasi, sehingga menghasilkan bentuk-bentuk tertentu menyerupai tangkai. Bentuk ini disebut patra, yang dalam Bahasa Sansekerta berarti daun atau surat. Fakta itulah mungkin yang menyebabkan hiasan patra selalu dilengkapi dengan daun-daun yang menjadi pokok variasi, meskipun daun itu sudah distilir dari bentuk aslinya. Tidak semua ragam hias tumbuhan ini mengandung nilai makna simbolik, sebab kadang hiasan ini ditekankan pada segi keindahan dan tidak menggambarkan jenis tanaman tertentu. Pada masa Hindu-Buddha tumbuhan yang sangat populer dan mengandung makna simbolik di antaranya adalah pohon Kalpataru yang dianggap sebagai pohon keramat yang menyatukan 
dunia atas dan dunia bawah, di samping merupakan sumber segala kehidupan, kekayaan, dan kemakmuran. Bunga yang memiliki makna simbolis adalah bunga teratai yang dalam penggambarannya dibedakan bentuk, warna, dan namanya. Padma adalah teratai merah sedang mekar, penuh terlihat dari samping, sehingga terlihat jajaran kelopak berlawanan arah ke atas dan ke bawah. Utpala adalah teratai biru, digambarkan dalam keadaan setengah terbuka. Daun bunga tidak terlalu lebar, serta jumlahnya sedikit tidak bergelombang. Kumuda berupa teratai putih, digambarkan dengan bunga yang lebar tetapi runcing, jadi seperti bunga teratai yang sedang mekar penuh dilihat dari depan Kedua jenis ini banyak dipahatkan pada relief-relief candi di Jawa seperti pada Candi Borobudur, Mendut, dan Prambanan (Atmosudiro dkk 2008, 189-191).

\section{Ragam Hias Bentuk Manusia}

Tidak semua bagian tubuh manusia ditampilkan dalam seni hias, bagian tubuh yang sering dimunculkan adalah bagian muka. Pada masa Hindu-Buddha, muka ditampilkan pada ambang pintu, relung, dan jendela candi berupa kala. Kala diyakini mempunyai arti sebagai lambang penangkal segala sesuatu yang jahat. Kala pada candicandi digambarkan dalam bentuk demonial face dengan ciri-ciri: mata melotot, gigi dan taring menonjol keluar, dan tangan terbuka di kiri kanan mulut (Widyatmanta 1958, 48). Sebenarnya sejak jaman prasejarah penggambaran wajah manusia sudah ada antara lain terdapat pada kedua sisi sarkofagus yang ditemukan di Bali oleh R.P. Soejono. Tonjolan yang berbentuk kepala manusia dengan menjulurkan lidah, dianggap memiliki daya pengusir roh jahat yang akan mengganggu si mati yang ada di dalam sarkofagus tersebut (Soejono 1962, 210-250). Juga penggambaran manusia dalam sikap kangkang dan genitalia merupakan lambang harapan akan kemakmuran, kesuburan, keselamatan, dan kehidupan kembali untuk para arwah. Demikian pula sebagai hiasan pada waruga yaitu peti kubur batu yang merupakan makam leluhur suku Minahasa, Sulawesi Utara pada zaman dahulu. Waruga tidak saja merupakan salah satu jenis pemakaman kuna, tetapi juga peninggalan sejarah sekaligus monumen dengan ciri khas yang berakar pada kebudayaan megalitik. Ragam hias manusia kangkang ini mengalami perkembangan sampai sekarang, dan dapat dilihat pada corak kain tenun dari berbagai daerah di Indonesia. Motif ini dapat dilihat pada tenun Sumba dan Toraja.

\section{Ragam Hias Bentuk Binatang}

Sejak masa prasejarah, motif binatang sudah dikenal dan berkembang sampai pada masa klasik. Tujuan penggambaran binatang ini sebagai hiasan dekoratif dan naratif untuk cerita dengan tokoh binatang seperti cerita Jataka dan Tantri (Atmosudiro 2008, 177). Contoh penggambaran binatang gajah, dianggap mempunyai peranan penting dalam agama Hindu yang diyakini sebagai lambang Ganesha dan dalam agama Buddha sebagai wahana Buddha Gautama (Poerbatjaraka 1957, 21). Penggambaran binatang cecak atau biawak dianggap sebagai penjelmaan Mahakala yang dapat mencegah malapetaka ataupun perbuatan jahat. Candi-candi yang memuat relief cerita antara lain: Candi 
Ragam Hias Non-Cerita pada Relief Candi

untuk Perkembangan Motif Batik Kontemporer 64-78

Borobudur, Candi Prambanan, Candi Sukuh, dan banyak lagi relief cerita yang menggambarkan manusia atau binatang. Contoh lain adalah relief Candrasengkala seperti pada Candi Sawentar, dan Candi Panataran di Jawa Timur. Relief tanpa cerita lain terdapat di kompleks Candi Gedongsongo, dan kompleks Candi Dieng (Atmosudiro 2008, 167). Relief candi yang berupa cerita (naratif) sudah banyak ditulis oleh beberapa ahli, di antaranya oleh Maria J Clock yang menulis tentang seluruh relief bertemakan Tantrik yang ada pada candicandi di Pulau Jawa.

Candi-candi baik Hindu maupun Buddha, biasanya mempunyai ragam hias yang digoreskan pada bagian-bagian tertentu tubuh candi, mulai dari kaki candi sampai bagian atap candi. Relief menggambarkan bermacam-macam bentuk, antara lain: manusia, tumbuh-tumbuhan, binatang, dan hiasan geometris. Hiasan geometris dipakai untuk menghias bagian tepi atau pinggiran suatu benda dan diterakan sebagai pengisian dari bagian benda pada permukaan bidang yang rata. Dapat juga sebagai inti atau bagian yang berdiri sendiri dan merupakan unsur estetik dalam bentuk ornamen arsitektural. Relief simbol religius, ornamennya berhubungan dengan arti dan makna keagamaan yang menjadi latar belakang pendirian candi tersebut (Toekio 2000, 38).

\section{Ragam Motif, Bahan Kain, dan Makna Simbolis Batik \\ 1. Motif Batik}

Motif adalah pola atau corak hiasan yang terungkap sebagai ekspresi jiwa manusia terhadap keindahan atau pemenuhan kebutuhan lain yang bersifat budaya. Adapun batik adalah suatu seni tradisional asli Indonesia dalam menghias kain dan bahan lain dengan motif hiasan dan bahan warna khusus. Batik juga diartikan kain mori yang digambari dan diproses secara tradisional. Batik dalam bahasa Jawa berasal dari kata amba dan nitik. Amba berarti kain, dan nitik mempunyai pengertian berhubungan dengan sesuatu yang halus, lembut, dan kecil yang mengandung keindahan. Batik merupakan hasil penggambaran corak di atas kain dengan menggunakan canting dan bahan malam/lilin (Handoyo 2008, 3). Batik ada beberapa macam yaitu batik tulis, batik cap, dan perpaduan antara batik tulis dan batik cap disebut batik kombinasi. Budaya batik dikenal hampir di semua etnis di Indonesia. Oleh sebab itu, banyak sekali ragamnya. Ragam hias batik dibuat ada yang hanya untuk memenuhi selera keindahan, tetapi ada juga yang dibuat dengan tujuan Iain. Di Jawa hampir seluruh motif batik diciptakan dengan suatu harapan. Batik motif Sidomukti, misalnya, dibuat dengan pengharapan agar pemakainya dapat mengalami hidup mulia dan berkecukupan.

Demikian pula halnya dengan motif batik yang beraneka warna, dan semuanya mengacu kepada tradisi turun temurun, untuk memenuhi selera keindahan dan untuk tujuan lain yang bersifat simbolis religius. Banyak hal dapat terungkap dari ragam hias motif batik, seperti latar belakang kebudayaan, kepercayaan, adat istiadat, sifat dan tata kehidupan, alam lingkungan, cita rasa, dan tingkat ketrampilannya. Pada hakekatnya seni batik tersebut berasal dari nenek moyang bangsa Indonesia yang diajarkan secara turun temurun dari generasi ke generasi berikutnya. 
Ragam Hias Non-Cerita pada Relief Candi untuk Perkembangan Motif Batik Kontemporer 64-78

Akan halnya ragam hias sebagai hasil kebudayaan yang berkesinambungan dengan local genius/cultural identity kemampuan menyerap dan mengolah pengaruh kebudayaan sehingga dapat mencapai suatu ciptaan baru yang tidak ada pada wilayah bangsa yang membawa pengaruh budaya tersebut. Bangsa Indonesia secara keseluruhan sudah memiliki kemampuan itu sejak jaman dahulu (Soebadio 1985, 21-23). Perlu pula disimak pendapat Brandes yang mengatakan bahwa Bangsa Indonesia khususnya masyarakat Jawa pada jaman praHindu sudah mengenal 10 macam kepandaian yaitu wayang, gamelan, tembang (metrum), membatik, mengerjakan logam, sistem mata uang, pelayaran, astronomi, irigasi/pengairan sawah, dan pemerintahan yang teratur (Atmodjo 1979, 51).

Di Jawa Tengah, motif batik dibagi dalam dua golongan, yaitu sebagai berikut.

\section{a. Motif Batik Keraton}

Motif batik keraton identik berasal dari Solo dan Yogyakarta, oleh sebab itu batik keraton disebut juga sebagai motif batik SoloYogya. Motif batik keraton sebelumnya berkembang di lingkungan keraton/istana, sebagai sarana membuat bahan pakaian raja dan keluarganya. Saat itu batik dianggap sebagai karya yang langka, maka pengguna batik hanya terbatas untuk kalangan keluarga bangsawan (Anshori 2011, 11).

Batik Solo-Yogya bersifat simbolis atau perlambang dengan latar belakang kebudayaan Hindu dan Kejawen. Batik ini mempunyai ciri khas warna dominan yaitu coklat sogan, biru wedelan/indigo, hitam dan putih. Motif dasar dari batik Solo - Yogya ini antara lain:
(1) Motif sawat atau lar: melambangkan penguasa tinggi atau mahkota

(2) Motif meru/pagoda: melambangkan alam, bumi, gunung

(3) Motif naga: melambangkan air

(4) Motif burung: melambangkan dunia atas atau angin

(5) Motif modang/lidah api: melambangkan panas atau nyala api (Widyahartono 1989, 206).

Motif-motif dasar batik Solo - Yogya tersebut dibagi lagi menjadi banyak sub- motif antara lain:

(1) Parang, mempunyai 20 sub-motif antara lain: parang rusak, parang klitik, parang gurda, parang kusumo, dan parang barong;

(2) Geometris, mempunyai 42 sub-motif antara lain: kawung, jlamprang dan nitik rengganis;

(3) Sulur-suluran, mempunyai 38 submotif antara lain: semen, kembang gempol, dan sawat suri;

(4) Tumbuh-tumbuhan air, mempunyai 15 sub-motif antara lain: ganggong bronta;

(5) Kembang, mempunyai 24 sub-motif antara lain: Trumtum, ceplok dan grompol;

(6) Satwa dan alam kehidupan, mempunyai 65 sub-motif antara lain: sidomukti, gringsing, cuwiri, dan buntal;

(7) Banji/Swastika, hanya mempunyai 3 sub-motif yaitu: banji, banji bengkok (motif mirip kawung) dan banji guling (Widyahartono 1989, 207);

(8) Isen-isen, merupakan motif tambahan untuk mengisi bidang yang kosong pada kain. Isen-isen umumnya berukuran kecil dan dibuat 
Ragam Hias Non-Cerita pada Relief Candi

untuk Perkembangan Motif Batik Kontemporer 64-78

setelah selesai membuat pola ragam hias utama. Isen-isen memiliki 33 sub-motif yang masing-masing mempunyai nama sendiri untuk setiap jenisnya. Proses pembuatannya membutuhkan waktu yang lama, sehingga menuntut kesabaran dan ketelitian (Handoyo 2008, 10-11).

\section{b. Motif Batik Pesisir}

Batik pesisir dipengaruhi oleh ragam hias yang berasal dari budaya asing terutama dari Cina. Bentuk gambar lebih bersifat naturalis, warna batik juga beraneka ragam seperti warna biru muda sampai ke warna biru tua, demikian juga warna merah, kuning, dan coklat. Batik pesisir yang terkenal adalah batik dari Pekalongan, Lasem, Cirebon, dan Madura. Motif Cina yang banyak dipakai sampai sekarang adalah motif yang menggambarkan binatang khayal seperti peksi naga, liman, mega/awan, dan singa barong.

\section{Bahan Kain Batik}

Para pembatik memiliki cara tersendiri dalam memilih kain yang akan digunakan sebagai bahan batik. Hal ini berkaitan dengan pengalaman selama mereka membuat kain batik secara turun

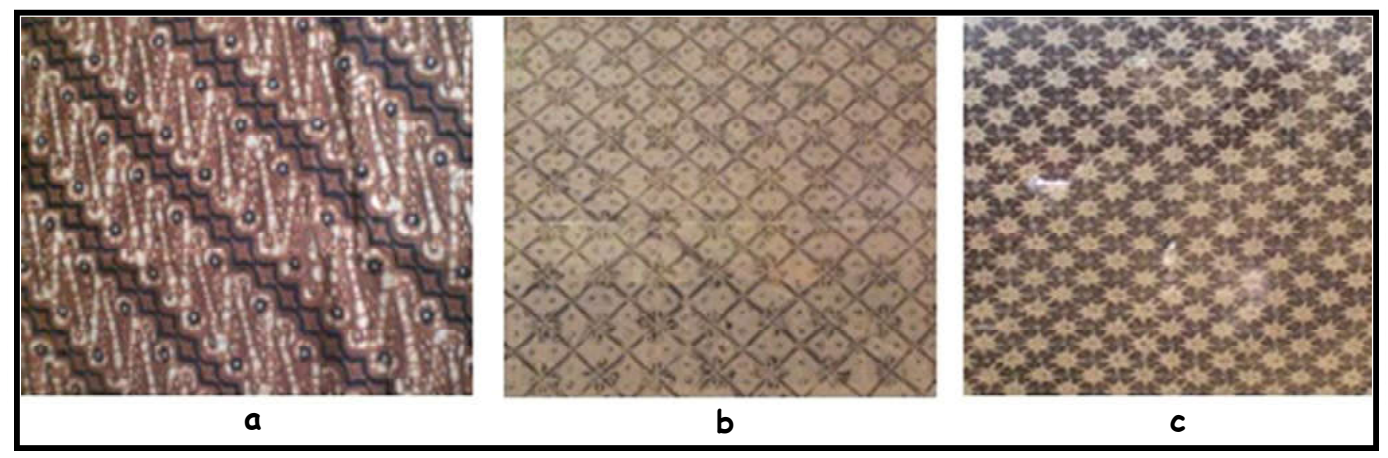

Foto 1. a) motif Parang; b) motif Kawung; c) motif Trumtum

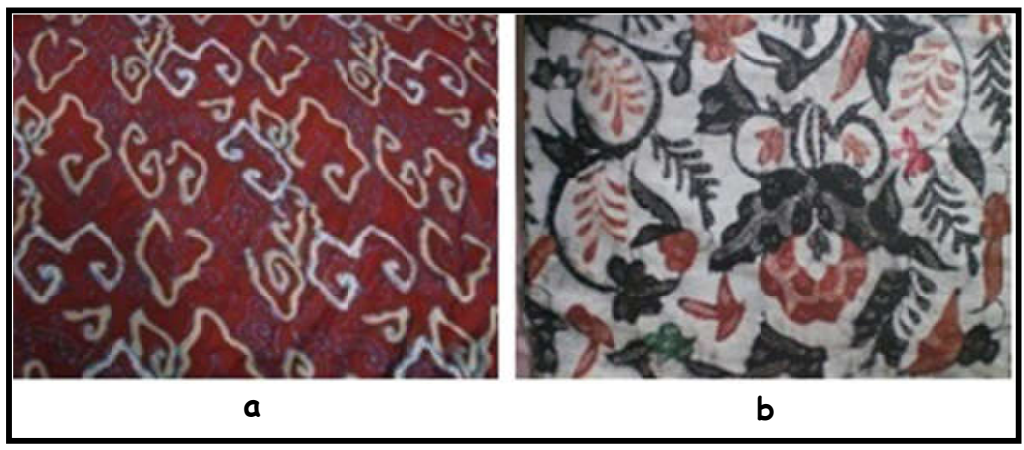

Foto 2. a) motif Mega-mendung; b) Batik Madura 
temurun. Jenis-jenis kain yang biasa dipilih sebagai bahan dasar batik ada dua macam yaitu: kain katun dan kain sutra.

\section{a. Kain Katun}

Kain katun adalah kain yang terbuat dari benang kapas yang dipintal. Katun dipilih sebagai bahan dasar karena sifatnya yang mampu menyerap kelembaban, dan memiliki daya tahan terhadap panas, sebab kain kapas bukan penghantar panas yang baik. Selain itu kain kapas memiliki keelastisan yang stabil. Secara umum, kain katun yang digunakan sebagai bahan batik disebut mori, yaitu tenunan benang yang kualitasnya ditentukan oleh kerapatan anyamannya. Kain mori kualitas bagus yang digunakan pada pembatikan di Jawa sebelum tahun 1800-an, masih didatangkan dari India. Kain katun yang dianggap memiliki kualitas tertinggi, bagi para pengrajin batik dikenal dengan istilah primis atau primissima. Primissima muncul lebih dahulu sebagai kain mori tanpa cacat tenunan, kemudian istilah primis muncul kemudian yang berarti prima atau sempurna (Anshori 2011, 32).

\section{b. Kain Sutra}

Kain sutra terbuat dari serat protein, yang diperoleh dari ulat sutra, sejenis serangga bombyx mori yang termasuk suku Bombyeidae. Ulat sutra mempunyai nilai ekonomi tinggi karena menghasilkan benang sutra. Mula-mula ulat sutra membuat jala dengan serat sutra pertama yang disebut flos. Setelah itu binatang tersebut membalurkan diri dengan serta sutra ke seluruh tubuhnya, dan dengan demikian membentuk kepompong. Serat ini tidak terputus, sehingga panjangnya mencapai sekitar 600-900 meter. Benang ini dihasilkan oleh dua kelenjar khusus yang terletak dekat rahang bawah. Bila terkena udara, cairan sekresinya akan mengeras. Ulat sutra menganyam kepompongnya dalam 3-5 hari. Sekitar 2-3 minggu kemudian, ngengat keluar dari kepompong dengan merobek kepompongnya, akibatnya serat sutra pun akan terpotong-potong. Oleh karena itu petani ulat sutra biasanya mengambil serat sutra sebelum ngengat keluar dari kepompong. Ulat sutra sebagai penghasil benang sutra sudah dikenal sejak beberapa ribu tahun yang lalu di Cina. Namun, dunia Barat baru mengetahui mengenai serat sutra ini sekitar tahun 300 SM. Meskipun demikian, sampai sekitar tahun 550 Masehi sutra sudah dibudidayakan di seluruh dunia, terutama untuk diambil seratnya (Prihatin 1991, 459).

Saat ini sutra yang ada di pasaran adalah sebagai berikut.

(1) Sutra import adalah kain sutra yang ditenun secara manual, dikenal dengan sutra Super, Organdi, Crepe, dan Kaca Kotak;

(2) Sutra lokal yaitu kain sutra buatan dalam negeri ditenun dengan alat tenun bukan mesin (ATBM);

(3) Antara lain, sutra polos, sutra granitan, dan sutra sulur;

(4) Sutra Liar, yaitu sutra yang dibuat dari serat ulat sutra yang dibudidayakan secara liar. Ulat-ulat sutra ini dibiarkan hidup dengan makan daun-daunan mahoni, murbei, kedondong, dan jambu mete. Jenis serta yang dihasilkan dari ulat pemakan daun jambu mete, murbei, dan kedondong, berwarna kuning keemasan. Sedangkan serat yang dihasilkan dari ulat pemakan daun mahoni berwarna coklat. Warna-warna tersebut adalah warna alami (Anshori 2011, 31-36). 
Ragam Hias Non-Cerita pada Relief Candi

untuk Perkembangan Motif Batik Kontemporer 64-78

Sekalipun teknik membatik di Indonesia sudah berumur ratusan tahun, namun masing-masing daerah dan para pengrajin batik memiliki cara-cara sendiri. Batik sutra biasanya lebih mahal harganya daripada batik bahan katun. Hal ini disebabkan karena sifat kain sutra yang lebih halus dan licin, sehingga proses pembatikannya memakan waktu yang lebih lama dan rumit.

\section{Makna Simbolis Batik}

Ragam hias atau motif batik di Jawa sangat banyak seperti yang telah disebutkan di atas. Setiap motif dibuat berdasarkan nilainilai luhur masyarakat Jawa dan tentu saja dianggap mempunyai arti simbolis. Dalam makalah ini, tidak akan diuraikan semua motif batik yang telah ada sejak jaman dahulu hingga sekarang. Hal ini disebabkan sangat banyaknya ragam hias yang terdapat pada relief candi, yang mungkin menjadi dasar ragam hias batik sekarang. Hanya beberapa motif yang dianggap merupakan pengembangan dari relief candi menjadi motif batik kontemporer di Jawa khususnya Jawa Tengah.

\section{a. Motif Parang}

Motif ini merupakan motif yang sejak dahulu dikenal oleh masyarakat Jawa pada umumnya dan dianggap sebagai motif tertua. Motif parang banyak variasinya dengan penamaannya yang berbeda-beda. Banyak cerita yang mengisahkan tentang motif parang, tetapi yang penting motif ini dianggap mengandung pralambang yang luhur, sehingga pada jaman dahulu yang diperkenankan memakai motif ini hanya para bangsawan tinggi. Waktu itupun motif ini tidak dipakai untuk pakaian sehari-hari melainkan hanya untuk peristiwa atau upacara penting yang diadakan oleh istana. Konon, motif ini diciptakan oleh Sultan Agung pendiri Kerajaan Mataram. Motif parang sesungguhnya menggambarkan senjata sejenis parang atau keris. Hal ini diasosiasikan dengan bentuk berkelok yang berada di antara pilin Selanjutnya Jasper dalam Kuswadji (1985) mengatakan bahwa motif parang berasal dari bentuk daun teratai yang mengalami perkembangan dari masa ke masa, sehingga terciptalah motif parang dengan berbagai macam motif seperti parang barong (khusus motif ini hanya dipakai oleh raja di Jawa).

\section{b. Motif Gurda: Sub-Motif Parang}

Motif gurda lebih mudah dimengerti daripada motif lainnya, karena bentuknya jelas dan mudah diterima oleh masyarakat luas. Kata gurda adalah kependekan daripada Garuda nama seekor burung besar yang menurut kepercayaan dahulu mempunyai kedudukan yang penting. Adapun bentuk motif gurda ini berupa sayap (Jawa = lar) di tengahtengahnya terdapat badan dan ekornya. Penamaan motif ini juga berbeda, apabila digambarkan dengan satu sayap disebut lar. Jika digambarkan dengan dua sayap dinamakan mirong, dan bila digambarkan dengan dua sayap dan satu ekor disebut sawat (Sunarya 2009, 25). Dalam Kitab Adiparwa disebutkan bagaimana pentingnya kedudukan garuda di tengah-tengah kehidupan para dewa Hindu, dan akhirnya dianggap sebagai binatang suci bahkan kemudian menjadi wahana dewa Wisnu, yakni salah satu dari dewa Hindu. Cerita tentang asal mula Garuda menjadi wahana dewa Wisnu adalah sebagai berikut. Suatu saat Garuda berperang melawan para dewa, dan dapat mengalahkannya. Kemudian para dewa 
mengutus dewa Wisnu untuk menemui Garuda dan terjadilah perang mulut yang dimenangkan oleh Garuda. Akhirnya Garuda mempersilahkan para dewa untuk meminta satu permohonan kepadanya yang akan dikabulkannya. Ternyata permohonan yang diajukan sangat sederhana, tetapi justru menunjukkan kecerdasan akal dewa Wisnu. Permohonan itu adalah agar Garuda bersedia menjadi kendaraan atau wahana dewa Wisnu. Oleh karena sudah terlanjur berjanji akan mengabulkan satu permohonan para dewa, terpaksalah Garuda memenuhinya. Sejak itulah dalam penggambaran tokoh dewa Wisnu selalu menaiki seekor garuda (Kuswadji 1985, 12).

Dewa Wisnu juga diyakini sebagai Sang Hyang Hari yang berarti matahari, sehingga garuda juga identik dengan lambang matahari atau disebut juga sebagai burung angkasa (lambang laki-laki), sedangkan lawannya lambang perempuan adalah ular sebagai penguasa bumi. Karena garuda mengandung pengertian sebagai lambang laki-laki, angkasa, dan matahari yang memberi kehidupan, maka motif garuda atau gurda diharapkan pengaruhnya bagi pemakai batik motif ini. Selain untuk ragam hias batik, garuda juga banyak dipakai dalam masyarakat Jawa misalnya dalam pewayangan, seni ukir, seni hias lainnya bahkan menjadi lambang Negara Republik Indonesia.

\section{c. Motif Lereng: Sub-Motif Parang}

Motif lain yang termasuk sub-parang adalah lereng, yang memiliki pola dasar garisgaris miring yang sejajar. Di antara garis-garis yang sejajar tersebut terdapat pilin kait atau pilin ganda seperti pada motif parang. Adapula yang menganggap motif ini diilhami dari sebuah lereng tanah berbukit. Selain itu, motif lereng juga dapat dihubungkan dengan pohon semacam talas yang dipolakan berdasarkan motif meander (Sunaryo 2009, 26).

\section{d. Motif Jlamprang: Sub-Motif Geometri}

Motif ini sebenarnya adalah motif cinde yang berasal dari Hindustan, sedangkan di Jawa biasanya disebut dengan motif nitik. Bentuk penggambarannya bulat, di tengahnya terdapat bulatan kecil seperti subang. Motif ini banyak terdapat di arca-arca dan reliefrelief candi Hindu-Buddha sebagai asesoris. Motif ini biasa digunakan untuk para bangsawan dan sangat digemari oleh masyarakat Jawa. Menurut Rauffer dan Joynboll dalam Kuswadji (1985), motif jlamprang diambil dari bunga yang memiliki delapan daun mahkota. Sedangkan dalam kepercayaan Hindu dan Jawa, jlamprang merupakan bentuk Yantra atau Cakra, keduanya sebagai lambang senjata dewa Wisnu yang bersinar delapan. Hal ini menunjukkan betapa pentingnya kedudukan bilangan delapan pada kepercayaan dan pandangan hidup masyarakat Jawa baik pada masa lampau maupun sekarang. Penggambaran motif jlamprang adalah bentuk cakra dengan lidah api delapan buah untuk menyinari dunia. Cakra sebagai senjata Wisnu juga mempunyai pengertian yang identik dengan matahari. Tentang bilangan delapan ini dapat dihubungkan dengan bangunan candi Hindu yang mempunyai delapan dewa penjaga mata angin/ Astalokapala. Pada pengaturan tentang candrasengkala, kata badan (Jawa) mempunyai watak delapan seperti 
pengejawantahan dewa Siwa/Mahadewa yang dapat diuraikan menjadi 8, yaitu Rawi = matahari, Saso = bulan, Kaiti $=$ tanah, Jala $=$ air, Pawana = angin, Hutasena = api, Jayamana = pemimpin suatu upacara keselamatan, dan Akasa = udara. Ada pula pendapat lain yang mengatakan bahwa dalam agama Hindu arah mata angin masing-masing dijaga oleh seekor gajah yang bernama: Airawata, Pindarika, Vamana, Kumuda, Ayana, Puspadanta, Sarwaboma, dan Supratika (Kuswadji 1985, 19). Dalam pandangan hidup masyarakat Jawa ada ajaran yang mengandung angka 8 yaitu Astabrata yang berarti 8 macam jalan hidup. Masih banyak lagi contoh-contoh tentang bilangan 8 yang dianggap sakral ini, dan karena alasan itulah motif batik jlamprang dibuat dengan tujuan agar pemakainya mendapat pengaruh yang baik-baik pula.

\section{e. Motif Tumpal: Sub-Motif Geometri}

Memiliki dasar segitiga, biasanya membentuk pola berderet, dan digunakan sebagai ornamen pada tepi kain batik. Motif

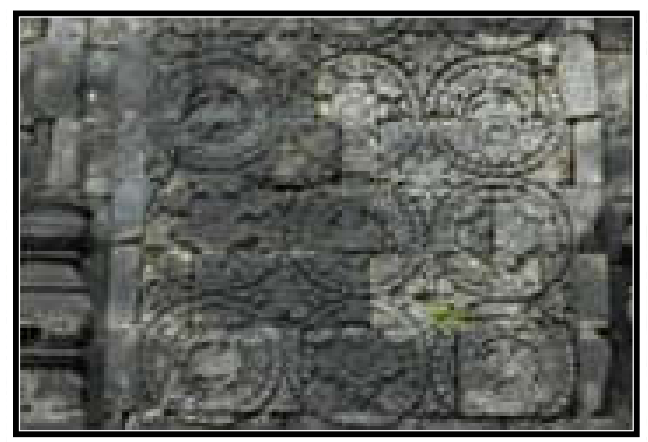

ini sudah ada sejak jaman prasejarah antara lain terdapat sebagai ornamen pada nekara perunggu. Ragam hias tumpal juga menghiasi bangunan candi-candi dalam berbagai variasinya berbentuk dasar segitiga sama kaki diisi oleh aneka motif tumbuhtumbuhan, seperti sulur-suluran, bahkan dapat pula terisi bentuk motif ragam hias lidah api. Motif ini mendapat pengaruh dari budaya Cina dan terlihat pada motif batik di daerah pinggiran atau pesisir-pesisir pantai (Hoop 1949, 26-30).

\section{Pengembangan Ragam Hias Non- Cerita Relief Candi pada Motif Batik}

Beberapa motif ragam hias noncerita relief candi dan motif batik di bawah ini, menunjukkan kemiripan. Meskipun tidak sama persis, tetapi dapat dianggap telah mengalami perkembangan kreativitas yang menghasilkan suatu kreasi baru, sekiranya dapat disejajarkan seperti digambarkan dalam perbandingan gambar berikut.

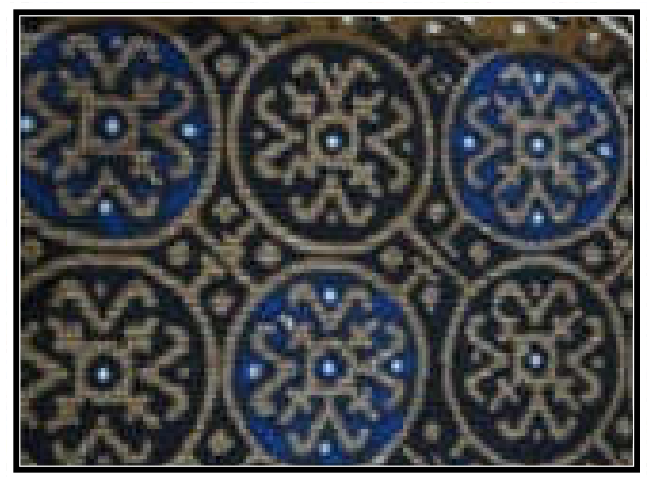

Foto 3. Aplikasi motif jlamprang sebagai motif sub-geometris (gambar sebelah kanan) yang berdasarkan ragam hias kertas tempel yang terdapat pada panil relief non-cerita di dinding Candi Sewu (gambar sebelah kiri) 

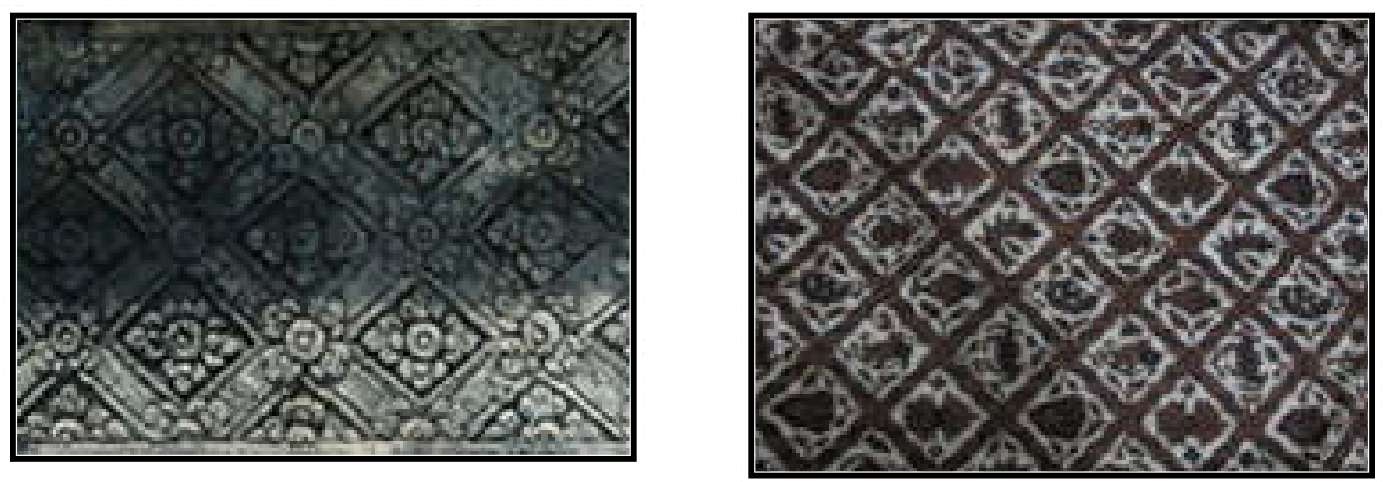

Foto 4. Motif Motif sub-satwa, sido asih dengan gambar fauna atau satwa (gambar sebelah kanan) yang berdasarkan ragam hias kertas tempel pada relief non-cerita di dinding Candi Plaosan (gambar sebelah kiri)
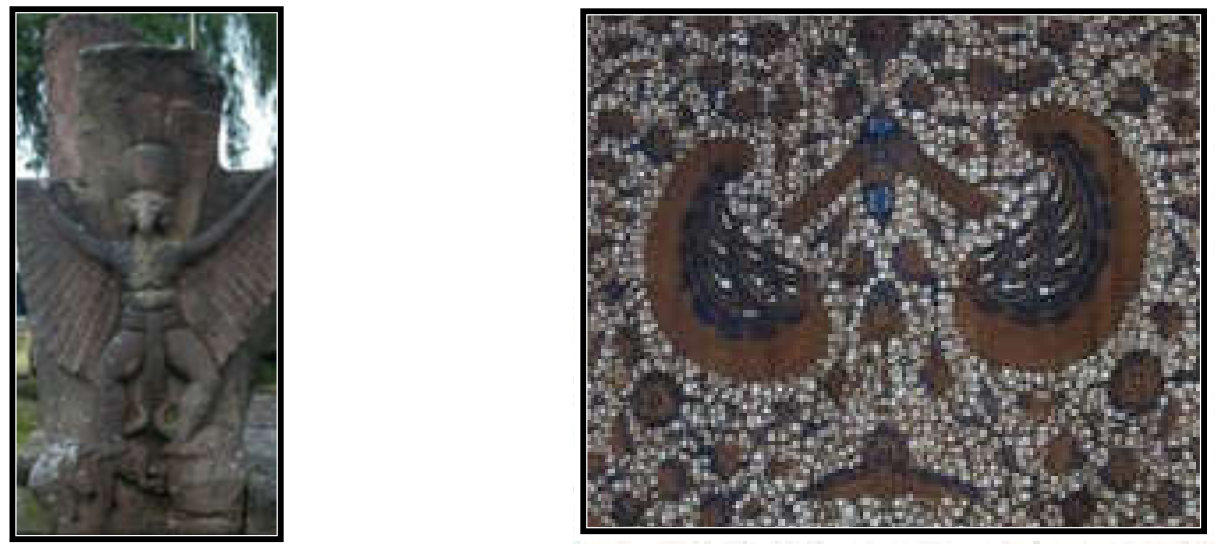

Foto 5. Motif sawat/lar, sub-parang (gambar sebelah kanan) yang berdasarkan ragam hias Garuda di Candi Sukuh (gambar sebelah kiri)
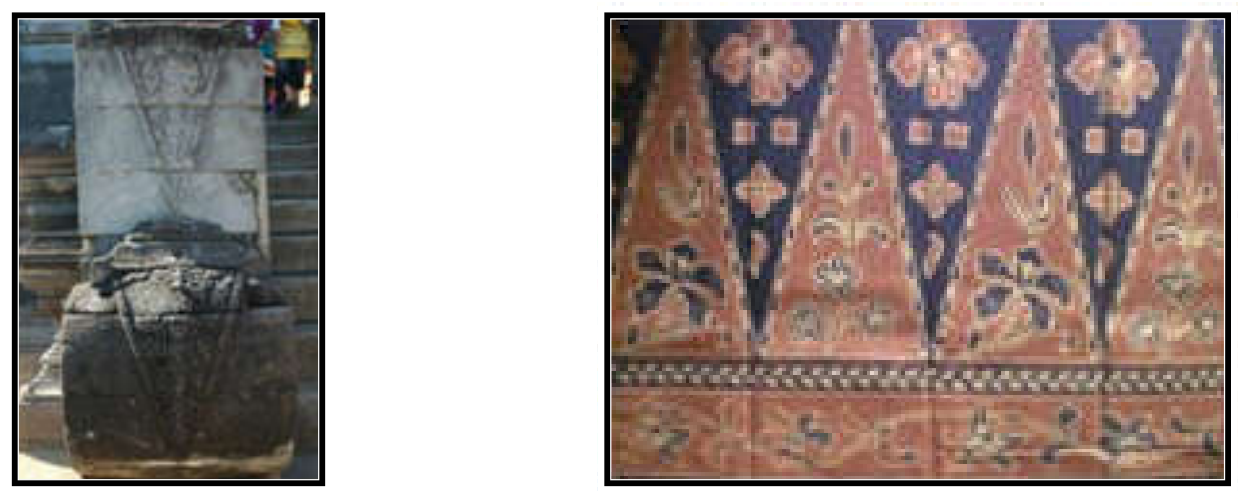

Foto 6. Motif tumpal pada pinggiran kain batik (gambar sebelah kanan) yang berdasarkan ragam hias geometris/tumpal pada relief non-cerita di dinding Candi Plaosan 
Ragam Hias Non-Cerita pada Relief Candi

untuk Perkembangan Motif Batik Kontemporer 64-78

\section{Penutup}

Ragam hias non-cerita pada relief candi sangat banyak variasinya, begitu pula motif batik yang sudah ada sejak dahulu sampai sekarang. Kalau disimak dengan seksama, tampak ragam hias relief candi yang mirip dengan motif batik. Apakah ini merupakan suatu kesengajaan untuk melestarikan warisan budaya nenek moyang Bangsa Indonesia, ataukah hanya merupakan suatu kebetulan saja? Hal ini dapat dimungkinkan bahwa ragam hias relief candi berasal dari pengaruh budaya Hindu-Buddha, selanjutnya "diambil" untuk motif batik. Sebagaimana pendapat Satyawati Soeleiman (1985) yang mengatakan bahwa unsur-unsur budaya dari luar dapat masuk ke dalam budaya suatu masyarakat, kalau dianggap cocok dengan pola kebudayaan yang sudah ada. Dapat juga dikatakan bahwa transformasi antara dua budaya yang masih murni diberi identitas lokal, atau menciptakan sendiri sesuatu yang dianggap hasil karya budayanya (Soeleiman 1985, 184).

Tulisan singkat ini mencoba menggugah minat para pengrajin batik untuk berwisata ke candi-candi, sambil memperhatikan relief-reliefnya. Berdasarkan relief candi tersebut, diharapkan dapat memunculkan kreasi-kreasi baru dengan latar belakang ragam hias relief candi-candi.

"Tiada masa kini bila tiada masa lampau, tiada masa depan bila tiada masa kini, sedang kebudayaan suatu bangsa menjadi tolok ukur tinggi rendahnya peradaban suatu bangsa"

Ungkapan sederhana ini merupakan hasil cetusan kesadaran sejarah manusia. Tinggi rendahnya peradaban suatu bangsa masa lampau dapat diukur dari mutu warisan peradaban yang berbentuk benda-benda bersejarah baik berupa benda seni apa saja maupun benda-benda peninggalan sejarah.

Segala tradisi dan peninggalan sejarah yang memberi corak khas kepada bangsa, perlu dibina, dan dipelihara untuk menumbuhkan kesadaran masyarakat akan kelestarian budaya yang telah berakar erat secara turun temurun. Kita harus bangga memiliki hasil karya seni yang bercorak ragamnya, sastra budaya, ilmu pengetahuan dan teknologi yang cukup tinggi nilainya, sejak jaman dahulu dan berkembang sampai sekarang. 
Ragam Hias Non-Cerita pada Relief Candi untuk Perkembangan Motif Batik Kontemporer 64-78

\section{Referensi}

Anshori, Yusak dan Adi Kusrianto. 2011. Keeksotisan batik Jawa Timur. Jakarta: PT Elex Media Komputindo Kelompok Gramedia.

Atmosudiro, Sumijati dkk. (ed.). 2008. Seni hias kuno. Dalam Jawa Tengah Sebuah Potret Warisan Budaya. Prambanan: Balai Pelestarian Peninggalan Purbakala Jawa Tengah bekerja sama dengan Jurusan Arkeologi Fakultas IImu Budaya Universitas Gadjah Mada.

Atmojo, M. M. Sukarto K. 1979. Struktur masyarakat Jawa Kuna pada jaman Mataram Hindu dan Majapahit. Yogyakarta: Pusat Penelitian dan Studi Pedesaan dan Kawasan Universitas Gadjah Mada.

Covarrubias, Miguel. 1973. Island of Bali. California: Periplus Edition.

Handoyo, Joko Dwi. 2008. Batik dan jumputan. Sleman: PT. Macanan Jaya Cemerlang.

Hoop, A. N. J. Th. van der. 1949. Ragam-ragam perhiasan Indonesia. Bandung: Koninklijk Bataviaasch Genootchap van Kunsten Een Weltenschappen.

Kuswadji, K. 1985. Motif batik dalam pandangan hidup masyarakat Jawa. Yogyakarta: Lembaga Javanologi.

Koentjaraningrat. 1990. Kebudayaan, mentalitas dan pembangunan. Jakarta: PT. Gramedia Pustaka Utama.
Prihatin, Iwan Tega. 1991. Eksiklopedi nasional Indonesia jilid 15. Jakarta: PT. Cipta Adi Pustaka.

Simanjuntak, Truman (editor). 2008. Metode penelitian arkeologi. Jakarta: Pusat Penelitian dan Pengembangan Arkeologi Nasional.

Sunaryo, Aryo. 2009. Ornamen Nusantara kajian khusus tentang ornamen Indonesia. Semarang: Dahana Prize.

Soebadio, Haryati. 1985. Kepribadian budaya bangsa. Dalam Kepribadian budaya bangsa (local genius). Jakarta: Pustaka Jaya, 18-25.

Soeleiman, Satyawati. 1985. Local genius pada masa klasik. Kepribadian budaya bangsa (local genius). Jakarta: Pustaka Jaya, 152-185.

Toekio, Soegeng, M. 2000. Mengenal ragam hias Indonesia. Bandung: Penerbit Angkasa.

Wagner, Firts A. 1959. The art of the world. Jakarta: Indonesia the Art of an Island Group.

Widyatmanta, Siman. 1958. Adiparwa I. Diterjemahkan oleh Seksi Bahasa Jawa Cabang Bagiab Bahasa. Yogyakarta: Jawatan Kebudayaan Kementrian Pendidikan dan Kebudayaan.

Widyahartono, Bob dan Endang Partrijunianti. 1989. Ensiklopadi Nasional Indonesia Jilid 3. Jakarta: PT. Cipta Adi Pustaka. 